\title{
A invenção das categorias travesti e transexual no discurso científico
}

\author{
Nossos corpos também mudam: \\ a invenção das categorias \\ "travesti" e "transexual" no \\ discurso científico.
}

LEITE JR., Jorge. Apresentação: Berenice Bento.

São Paulo: Annablume, 2011. 240 p.

Frequentemente, nos discursos de senso comum, as categorias transexuais e travestis são confundidas. Isto se dá não só na acepção dos termos, mas também na identificação dos sujeitos que assim se reconhecem. $O$ esclarecimento pela utilização de cada um dos conceitos através da construção do discurso científico norteou a pesquisa de Jorge Leite Jr., publicada no livro Nossos corpos também mudam.

A pesquisa parece surpreender 0 autor, assim como surpreende quem lê a obra, pois constata, com todo o resgate histórico efetivado, que as definições únicas e definitivas sobre corpos, identidades sexuais e seus limites entre masculinidade e feminilidade nunca existiram, assim como os termos travesti e transexual são criações recentes, já que, inicialmente, a figura conhecida, difundida e pesquisada era a do hermafrodita, hoje intersexual. O hermafrodita é o pai e a mãe das identidades transgêneras da segunda metade do século XX e do início do séc. XXI, nas palavras da Dra. Berenice Bento, que faz a apresentação da obra.

Como os limites entre masculinidade e feminilidade nunca existiram, o que se revela são tentativas de determinados grupos ou discursos em adequar uma situação a alguma das categorias criadas, que variam de grupo para grupo, como os médicos, religiosos, políticos, e também sofrem variações em épocas específicas. Isso fez com que, no decorrer do tempo, esses discursos se interpenetrassem até chegar ao que se tem hoje: uma disputa de poder dentro de um campo em que todos querem encontrar uma classificação adequada. Sob influência de Judith Butler e da teoria queer, o autor mostra como os discursos de gênero são construídos.

A tentativa inicial em estudar as categorias travestis e transexuais como se realmente fossem categorias standartizadas demonstra uma impossibilidade que decorre da miscelânea de ideias, vivências e estratégias da experiência concreta e cotidiana.

O conflito de identidade ou de identificação existente entre os próprios sujeitos trans e os que tentam categorizá-los vai muito além. Em que pese haver definições clínicas, constantes dos manuais em vigor - Classificação Internacional de Doenças (CID) e Manual Diagnóstico e Estatístico de Transtornos Mentais (DSM) -, a pesquisa mostra uma realidade completamente diferente: não há limites claros entre as próprias identificações das pessoas que se autodefinem como travestis, transexuais, gays, mulheres de verdade, drag-queens, crossdressers, transformistas, homossexuais masculinos extremamente afeminados, homossexuais femininas altamente masculinizadas.

Diante da profusão de corpos que se materializam e buscam legitimidade e reconhecimento no discurso, o foco de distinção ou de identificação não deixa de ser o corpo, mas como separar corpo, gênero e política, a não ser conceitualmente e dentro do meio científico?

Ao que a leitura denota, esse foi um dos questionamentos essenciais para o desenvolvimento da pesquisa, que conduz por diferentes épocas, ressaltando a contribuição de cada fase, 
de forma densa e crítica para a formulação do conceito científico de travesti e de transexual, baseados em normas sociais que organizam as diferenças de gênero.

Nas primeiras épocas analisadas, da antiguidade até o século XVIII, vigora o modelo conceitua sobre o corpo humano como possuindo sexo único, sendo os gêneros masculino e feminino reconhecidos pelo grau de evolução fisiológica da pessoa. No século XVIII, essa ideia começa a ser alterada de forma gradual, embalada pelas mudanças políticas, culturais e filosóficas.

Com essa demarcação inicial entre dois gêneros/sexos, havia proibição no tocante à troca de vestuários entre homens e mulheres, o que significaria também a troca de papéis sociais, sendo a troca de poder a mais grave consequência disso. Ao que parece, é essa proibição que dará início ao travestismo: a necessidade da mulher de ocupar determinados papéis na sociedade.

Pode-se afirmar que o travestismo e a transexualidade tiveram um início dissociado da sexualidade e do erotismo, bem como, que a questão trans é histórica e teve diferentes denominações e significados, ligados às representações de sexo e gênero em várias décadas.

Apesar de as referências iniciais demonstrarem uma demarcação entre os papéis de gênero, as ambiguidades sempre aparecem com a figura do hermafrodita. Essa tem como base os seres primordiais de Platão - os Andróginos e suas múltiplas encarnações na Idade Média e no Renascimento.

Observa-se que há referências mágicas, monstruosas e espirituais relacionadas ao hermafrodita, e isso vai prevalecer até que se consolidem as interpretações para o corpo humano no fim do século XVIII.

Com o início das ciências no século XIX, se naturaliza o homem, entendendo que a essência é o que atribui o gênero à pessoa, surgindo a noção de atração pelo gênero/sexo oposto como regra. Dessa forma, com o nascimento de pessoas que revelam os dois órgãos genitais (hermafroditas), discutem-se a cura e as cirurgias para descoberta do que se entende como "verdadeiro sexo".

Portanto, quando identificados os diferentes naquela sociedade, são emblemáticas as referências que demonstram a busca por uma justificativa, seja no campo espiritual ou sobrenatural. Quando a ciência e o racionalismo ganham espaço, o hermafrodita deixa de ser visto sob o viés da magia, passando a ser um desvio da natureza despertando, assim, a atenção das ciências psi.
Surge, então, o hermafrodita psíquico, que perde o seu lugar no corpo e passa a se alojar na mente. Com ele, vem a ideia de todos os perversos sexuais do século XIX, com demarcação dos discursos patologizantes, que, de certa forma, viabilizaram a integração dos travestis e transexuais na sociedade.

No século XIX, as terminologias associadas às monstruosidades acabam sendo substituídas pelo termo intersexo, cunhado, em 1917, por Richard Goldschmidt. A partir de então, o meio científico se ocupa do estudo dos casos denominados distúrbios do desenvolvimento do sexo e anomalia da diferenciação sexual. Porém, não há unanimidade entre os pesquisadores da época (como também não há hoje) que buscam as mais distintas classificações, partindo da figura do hermafrodita.

Até o século XVIII, as questões de aparência, comportamento, posição social, roupas e espiritualidade eram tomadas como um bloco único. Somente no auge da separação científica entre corpo e mente é que a ideia do hermafroditismo vai se fragmentar.

Todas as questões culturais ligadas a esse debate passam a ser discutidas via biologia $e$ medicina, sendo as ciências psi que o enaltecerão, na busca por uma categorização dos ditos portadores de disfunções sexuais. Nesse período, fica clara a disputa entre os autores e pesquisadores. Hevelock Ellis, Magnus Hirschfeld, Richard Von Kraff-Ebing, Harry Benjamim, John Money, Robert Stoller são alguns dos autores citados em suas tentativas de classificação com os termos: aberrações sexuais, bizarros, invertidos, anormalidade, desordem, perversão e condição perniciosa, os quais atribuem tanto às pessoas travestis como às transexuais.

Fica claro que até a segunda metade do século $\mathrm{XX}$ o conceito de transexual não existia, pois, nessa época, dos estudos efetivados por Richard Von Kraff-Ebing, uma referência se destaca. O caso de um homem nascido na Hungria que, após a adolescência, passa a se sentir e viver como mulher - e, assim, acredita que é - torna-se uma referência, sendo a mais antiga sobre o tema, numa narração autobiográfica. A descrição torna-se quase um roteiro do que serão as futuras narrativas das pessoas chamadas transexuais, sendo referência, porque pela primeira vez, não há traços de hermafroditismo. Nesse caso, Krafft-Ebing se refere ao estágio de transição para a ilusão de mudança sexual, como um tipo de confusão mental que faz a pessoa crer que está num corpo sexual errado. Desse caso, nascerá uma linha de análise 
científica e, ao surgir o conceito de transexual tais pessoas não serão mais vistas como psicóticas em delírio, e haverá uma tendência a favor das cirurgias de transgenitalização.

Com tudo isso, revela-se, primeiro, a sociedade disciplinar que tenta categorizar tudo que fuja do normal, partindo da referência heteronormativa. Depois, a transição da sociedade disciplinar para a de controle das práticas sociais, que resultam numa série de limitações sobre os papéis sexuais. Após refletir sobre os discursos da psiquiatria, psicologia e psicanálise, com a análise da origem dos termos travesti e travestismo, o autor aborda a questão do surgimento das identidades de gênero e a importância da mídia na difusão dos conceitos a elas relacionados.

Começa a crítica a pressupostos universalizantes e naturalizados: a mulher, o homem, o corpo, o sexo e as dualidades sexo/gênero, masculino/feminino, ativo/passivo, homo/hetero, natureza/cultura, mostrando as lacunas e as contraposições dos padrões impostos e socialmente reguladores.

O autor analisa como essas questões se realizam no Brasil, onde a temática da transição de gênero, dissociada de sua origem marcada pela associação com a criminalidade e a prostituição, ainda em 1895, começa a ser rediscutida após os anos 1980. Ressalta o caso da modelo Roberta Close, no tocante à transexualidade e às políiticas de inclusão das travestis, mostrando como o termo está associado ao imaginário do desregramento sexual

$\mathrm{O}$ autor consegue conduzir-nos a um mergulho investigativo, histórico e crítico a respeito da formulação das nomenclaturas travesti e transexual, sem deixar de lado o seu desejo expressado no início da obra: "contar histórias sobre corpos que assumem diferentes formas e mudam".

Por isso, concluímos que, se adotarmos o discurso da performatividade de gênero discutido por Butler e aceitarmos as possibilidades de trânsito de gênero, poderemos entender a existência da travestilidade e da transexualidade. pois, sem qualquer intervenção estética, vestual, hormonal e cirúrgica, os nossos corpos também mudam.

Melissa Barbieri de Oliveira Universidade Federal de Santa Catarina

Miriam Pillar Grossi Universidade Federal de Santa Catarina 